\title{
Evaluating Training Effectiveness: Critical Studies in the Last Eight Decades
}

\author{
Mohamad Kenan Assi, Valliappan Raju
}

\begin{abstract}
The paper is an attempt to provide an influential and critical discussion to a very wide range of papers which could be ranged between the 1970s until 2020. A thorough discussion that influences training, organizations, trainers, and trainees was provided aiming at evaluating the training effectiveness. The paper has concluded that training could be more effective when organizations focus on the content of the training that is aligned with the strategical goal of the organization. The study has shown the effect of factors that have the highest priority to achieve the best training effectiveness. These factors include motivation, attitude, emotional intelligence management support, style of training style, trainer's open-mindedness, self-efficacy, and basic ability. These factors were determined throughout many studies as the dominant factors. This means that ensuring better training effectiveness, managers have to allow employees to practice the acquired skills due to training at the workplace. The attitude of the trainees could be used as a criterion to make an initial assessment of how much the training effectiveness has been achieved. However, the huge success of studies about evaluating the training effectiveness, it seems that more studies are still needed in at least three dimensions: influence of motivation, the attitude of employees, and developing a better model.
\end{abstract}

Index Terms - Training, Training Effectiveness, Motivation, Psychology, Attitude.

\section{INTRODUCTION}

The Human Resource Capital (HRC) has recently shown an influence on structuring organizations in terms of size, goals, and performance (Nankervis et al., 2019). To achieve these goals, organizations, health facilities, government agencies, and educational institutions have adopted training on- and off-job locations (Pendić et al., 2019). Having organizations adopted training, the next step is to investigate the impact of the training on the performance (creativity) of those employees who were involved in at least one training. However, organizations have been increasingly becoming conscious regarding the incurred cost and the methodology of conducting training (Noe \& Kodwani, 2018; Cameron \& Green, 2019). In the first place, HR and training professionals have found the status cumbersome due to limited choices available. The most important challenge is how to measure the effectiveness of the training (Johnston et al., 2018). Since 1976, experts and researchers have been

Mohamad Kenan Assi, Post graduate Center, Limkokwing University of Creative Technology, Kuala Lumpur, Malaysia

Valliappan Raju, Associate Professor at the post-graduate center at Limkokwing University of Creative Technology trying to develop suitable models for measuring training performance utilizing first a "four-level evaluation model" (Kirkpatrick, 1976) followed by other proposals (Sangwa \& Sangwan, 2018). There are two matters that have to seriously considered; firstly, setting specific training objectives and, secondly, preparing well the training material and the methodology (Zatsiorsky et al., 2020).

Training is defined as: "educational activities within a company to enhance the knowledge and skills of employees while providing information and instruction on how to better perform specific tasks." (Noe \& Kodwani, 2018). However, a more recent definition of training proposed by Banfield $e t$ al. (2018) states that training is: "an integral part of human resource development."

The training aims at fostering the growth of both the individuals and the organization by adopting a sequence of the well-ordered procedure through which gaining knowledge and experience are carried out. The training was described earlier by Flippo (1976) as "an application of providing awareness of rules and guidance towards better behavior," and supported very recently by Zatsiorsky et al. (2020). The basic goal of training is to provide the bridge that connects job requirements and employee specifications (Hoel \& Mason, 2018). The most influential opinion concerning the training was suggested by correlating training to evaluation methods followed by showing results which are considered as a sign of the success of the organization (Punia \& Kant, 2013). Individuals and organizations are benefiting from training hoping to increase confidence and self-efficacy and to improve competencies and skills (Hernawati et al., 2018).

Training effectiveness refers to attaining desired objectives or the expected results set by human resources because training is an essential part of HR activities (Sitzmann \& Weinhardt, 2018). It has been widely assumed that training supposedly to increase the capabilities of employees and the organization as well. Firstly, showing that the training has achieved the goals should take into consideration for conducting training. Based on this approach, the contents of the training and training quality course have to be clearly defined before conducting training and for this reason, they were highly considered as key factors. Otherwise, training may lead to different purposes away from the original plan resulting in ineffective training and adding pressure on both the organization regarding incurred cost and loss of reputation and on trainees in terms of the bad experience and failure feeling (Wenger et al., 2019). The other factor that affects the training effectiveness is the motivation of trainees which has to be honored always as the key element for improving the 
effectiveness of training outcomes (Sitzmann \& Weinhardt, 2018).

Measuring the effectiveness of training has not empirically set because there is no direct or absolute method to measure this effectiveness; yet, this can be achieved by measuring the difference of some criteria between pre- and post-training (McDavid et al., 2018). The evaluating of the training effectiveness can be performed to all industrial, commercial, educational, and governmental organizations and/or agencies (Morrison et al., 2019). The effectiveness assessments could rely on considering the influence of training interventions based on involving comparable data. This approach is no easy task for the organization; however, a possible approach can be performed by obtaining pre-training data or benchmark using the same expected dimensions from training interventions (Bowman et al., 2020). Historically, Kirkpatrick's (1967) proposed a 4-level model for training effectiveness training and then revised later by Aluko \& Shonubi (2014). The latest revision was based on Kirkpatrick's model fused with Baldwin's Transfer of Training Model creating the second level of Kirkpatrick's model using a mixed-methods inquiry. Briefly, assessing training effectiveness has been performed with the aid of some combinations that were presented earlier by training outcomes. The last approach is composed of four levels of training outcomes include the reaction of the trainees the program content and the process, acquisition of skill and knowledge, changing behaviors, and the tangible improving individuals and organizations, as well (Prifti et al., 2018).

The current paper discusses many factors affecting positively and negatively training effectiveness in both ways by pointing out models that are involved in training effectiveness. This review sheds the light on the importance of the training as a focal point that employees and organization developing their effectiveness. The study benefits HR management to follow an easy and possible approach to achieve the goal of the training effectiveness in organizations. Another depth of this study lies in solving training implementing successfully. The review focusses on presenting the most important factors towards achieving the best effectiveness.

\section{MODELS OF TRAINING EFFECTIVENESS}

As mentioned earlier, there is no absolute procedure to measure training effectiveness; however, indirect methods could yield to the relative estimation of the training effectiveness (Postolache et al., 2017). For this reason, several models have been proposed to make measuring training effectiveness plausible which was started as early as by Kirkpatrick's (1967) and followed by other studies where the focus was on various fields such education and others (Landers \& Armstrong, 2017). Kirkpatrick (1967) had identified four levels for evaluating training effectiveness: reaction, learning, behavior, and results as shown in Figure 1. In Level-1, the reaction of participants to the training is evaluated based on trainees' attitudes. Level-2 evaluates the acquired knowledge gained from the training materials by the trainees according to the specified program. The behavior is the next level, Level-3, in which the evaluation stresses the extent that the trainees adopted the value of training into the behavior or, simply, how the performance of the trainees being enhanced. The last level, the fourth, explains the results or the outcome of the program given on both the trainees and the organization's improvement.

Training effectiveness determined by
(a) Reaction : Trainees' reactions to the
content and training process
(b) Learning: knowledge or skill acquisition
(c) Behavior: Behavior change
(d) Results: Improvements in outcomes such
(d)
(d) as turn- over, accidents, or productivity.

Figure 1. The four-level of training effectiveness (Adopted by Kirkpatrick, 1967)

The second development regarding modeling the training effectiveness was the improvement proposed by Noe (1986) in which the motivation was added to Kirkpatrick's model as detailed in Figure 2. The model suggests that motivating trainees are performing the tasks and perceiving high effort leading to high performance, high performance leading to high-job performance, and high job performance leading to achieving desired outcomes and avoiding undesirable outcomes. Motivation can be described in two ways: motivation to learn and motivation to transfer training (Homklin, 2014). The motivation to learn combined with the self-efficacy influence Level 1 (the reaction) which has already by Kirkpatrick's (1967). The motivation to transfer training combined with the social support influence Level 2 (the learning) which was proposed by Kirkpatrick's (1967). Meanwhile, Level 3 (behavior) interacts with the individual's and organization's characteristics leading to enhance overall behavior. The results (Level 4) are split into impacts one influences individual and the other influences the organization. Hence, Noe's model is strictly correlated with motivation which was implicitly mentioned in Kirkpatrick's model. Moreover, a decade later Swanson \& Sleezer (1987) proposed another, simplified model to measure the training effectiveness by setting a plan, required tools, and then performing the evaluation report.

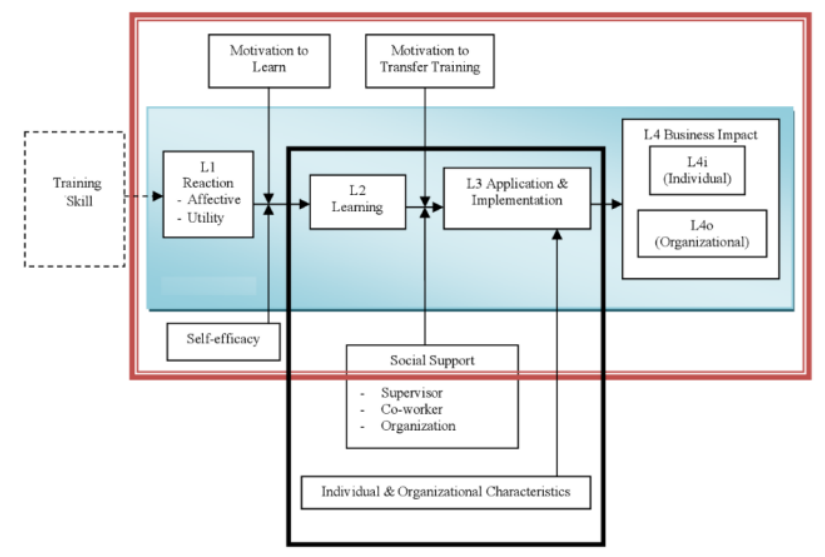

Figure 2. Noe's Model (Adopted from Homklin, 2014)

The factors that affect the training were demonstrated earlier by Shepherd (1999) and later by Sitzmann \& Weinhardt (2019). These factors include economy (direct cost and indirect cost), outcome (efficiency, performance to schedule, 
and performance change), and procedure (reactions, learning, and behavior change). In addition to these factors, Zaciewski (2001) introduced social factors belong to the employee's individual characteristics such as motivation, attitude, and basic ability. The latest factors were supported recently by Van Loon et al. (2018) who researched training in the public service organization. Recently, the influence of the environment was presented as a major factor in making a successful training programme (Noe \& Kodwani, 2018). The improvement of training was viewed by Burke \& Baldwin (1999) who proposed transfer of training can be enhanced in real-world organizational problems, while Dahiya \& Jha (2011) proposed other means to improve training such as planning, programme implementation, and programme evaluation and follow-up.

\section{FACTORS AFFECTING TRAINING EFFECTIVENESS}

In this section, the emphasis will be on literature that explores the factors affecting training effectiveness. As a rule of thumb, training is no different from all those issues affected by either direct, indirect, or both factors. In reality, there is a wide range of those factors that influence the effectiveness of the training and the subsequent developing organizations. As earlier indicated by Haywood (1992) that the human resource policy of training and development was the major factor. This conclusion was supported later by several authors (Bisharat et al. 2017; Hammond \& Churchill 2018; Berman et al. 2019; and Armstrong \& Taylor 2020). In the original study of Haywood (1992), most of the training programmes have emphasized on ease and the purpose behind the design of programs concerning learning, skill development, and behavioral change while, on the contrary, the original purpose and goals of the training are lost. In this regard, it was found that poor management has played a negative role in creating creative training and subsequent implantation (Birdi, 2005). Open-mindedness was another factor that was found to have a role in the training effectiveness besides that it can be considered as a moderator in the process (Punia \& Kant, 2013). Moreover, Driskell et al. (2018) have pointed out that the type of training implemented, training content, and trainee expertise was also important in training effectiveness. The success of the training programmes relies on the following three factors: training quality, training content, and the capability of the trainer (Collins et al., 2019). However, the success of training faces challenges such as governmental support, employers, and trainees' attitudes (Haslinda \& Mahyuddin, 2009).

The individuals' attitudes during the training sessions were found very important in providing service quality in banks as reported by Beigi \& Shirmohammadi (2011) and in public services as reported by Lee et al. (2018). In addition, psychological conditions such as motivation, self-efficacy, perceived control, and the realities of the organizational context affect the training outcomes (Saks \& Haccoun, 2007). Self-efficacy, in particular, was highlighted by Tai (2006) as a determinantal factor affecting the relationship between training motivation and training framing. Another opinion about the training factors was mentioned by Black \& Mendenhall (1990) who claimed that cross-cultural skill development, adjustment, and performance.

\section{TRAINING MOTIVATION}

The motivation was found as the main factor that affects the effectiveness of training (McCandlish et al., 2018). As early as the 1980s, the term "training motivation" was used by (Steers \& Porter, 1983) to show the strength that influences enthusiasm of the training programs in terms of stimulating participants to acquired knowledge in a training situation. The concept of "training motivation" then was developed through implementation in assessing the performance of both; the training program and the trainee's performance (Roberts et al., 2018). Besides, between the 1980s and 2020s, there has been plenty of research about the relationship between motivation and training (Scaduto et al. 2008; Tabassi et al. 2012; Renah \& Setyadi 2014; and Shaban et al. 2017) The relationship between employees' attitude and motivation was proposed by Bumpass \& Wade (1990) who emphasized on the existence of such a relationship high-possibility to estimate the performance of the employees in Australian organizations. The authors concluded in their study that the motivation towards training programme could bring about changes in performance. About five years later, Tracey, et al. (1995) conducted a study on the managers of 52 US supermarkets and found that attitude and motivation could improve the training quality and performance. Later, several factors such as the locus of control, anxiety, cognitive ability, and job involvement were found as predictors predicting motivation (Colquitt, et al., 2000). In a different move, Sahinidis \& Bouris (2008) investigated the relationship between employees' perception and training effectiveness, satisfaction, and commitment and found a strong correlation. The choice of the employees to attend freely or not the training program was studied by Tsai \& Tai (2003) and later by Mone et al. (2018). The results of these two studies showed that those employees who voluntarily or willingly are more motivated than those who were chosen to perform training.

\section{TRANSFER OF TRAINING}

The training is the first stage where trainees acquire knowledge and experience; however, transferring training is also a very important stage to physically practiced and experienced (Sridhar et al., 2017). Training passes from the trainer, to the trainees, and to an organization, a company, or an institution highlighted with better skill, deeper knowledge, and enhancing the performance of the organization. However, in 2014, Baldwin \& Magjuka (2014) declared that "learned behaviour" is the one that controls transferring of training due to that that this behaviour carries skills as well as the mechanism that the organization receives this skill. Meanwhile, Saks et al. (2010) interpreted training transfer as knowledge and skills generalization learned overtime before, during, and after training.

Collectively, the factors that affect training motivation are divided into behavioral such as emotional intelligence, 
employees' attitude, the open-mindedness of trainers, and trainees (Sahoo \& Mishra, 2019). The second-factor category is related to psychology such as the understanding level of trainee, self-efficacy, perceived control, and basic ability (Stajkovic et al., 2018). The last category of factors involves training implementation, content, expertise, managerial support, and job-related factors (Fadelelmoula et al., 2018). Training plays an important role in development (Noe \& Kodwani, 2018).

The development takes place throughout several measures such as knowledge increase, anxiety reduction, creation of new demands, and skill, attitude, and behavior development (Buchanan \& Huczynski, 2019). Training is described as effective when trainees, trainers, and organizations achieved full awareness regarding methods, models, and style, acquiring emotional intelligence, fulfilling the factors that affect training (Glerum et al., 2020).

\section{IMPORTANCE OF TRAINING EFFECTIVENESS}

The issue of training effectiveness is very important to the organization which spends effort and money hoping the trainees acquire enough skill to benefit the organization. This approach was built on a commercial and economical equation whose outcome should surpass the total cost of the training. This surpass of the balance refers to the effectiveness. In principle, the key aspect of the company's success should be clearly identified and recognized (Noe \& Kodwani, 2018). In 2011, Quesada, et al. (2011) has examined the first factor that was widely considered as the key factor in company success, $i$ $\mathrm{e}$, the emotional intelligence training of the leaders. The strength of the leader's emotion is the criteria that any company should implement. As noted by Lee et al. (2018) that the training is tremendously important to effective management. In addition, Mat et al. (2011) concluded that training resulted in increasing the knowledge, skills, and attitudes aspect of the trainees themselves after an industrial training programme.

The other issue is the awareness of the trainers in the sense of understanding the style of the trainees to achieve desired outcomes as noted earlier by Robotham (1995) and very recently by Sousa \& Rocha (2019). However, the question of evaluating the effectiveness, Rama \& Vaishnavi (2012) proposed that the effectiveness is directly related to achieving the needs of an organization. In educational institutions, Mooi (2010) has found that an effective teacher has shown dependency on participants' perception and research-based practices. Concerning the management development activities, Jayawarna et al. (2007) found a positive impact on performance of manufacturing companies. The training was found also to reduce the anxiety experienced by employees due to the work environment as noted by Chen, et al. (2004). Briefly, determining the effectiveness of the training is not a simple task; it is rather, very complicated as described by Santos (2003) and recently by Alaqeel \& Aldoghmy (2018).

\section{MODELS FOR ESTIMATING TRAINING EFFECTIVENESS}

There are three models that are used to measure the training effectiveness: Krikpatrick's four level model
(Kirkpatrick \& Kirkpatrick, 2006), Noe's model (Noe \& Schmitt, 1986), and Swanson \& Sleezer's three step model (Swanson \& Sleezer, 1987). Krikpatrick's four level model is explained in Figure 3 showing the four levels in inverted pyramid starting with reaction, learning, impact and results. In each level, there is an assessment for that level which collectively turns the assessment into evaluation of the training.

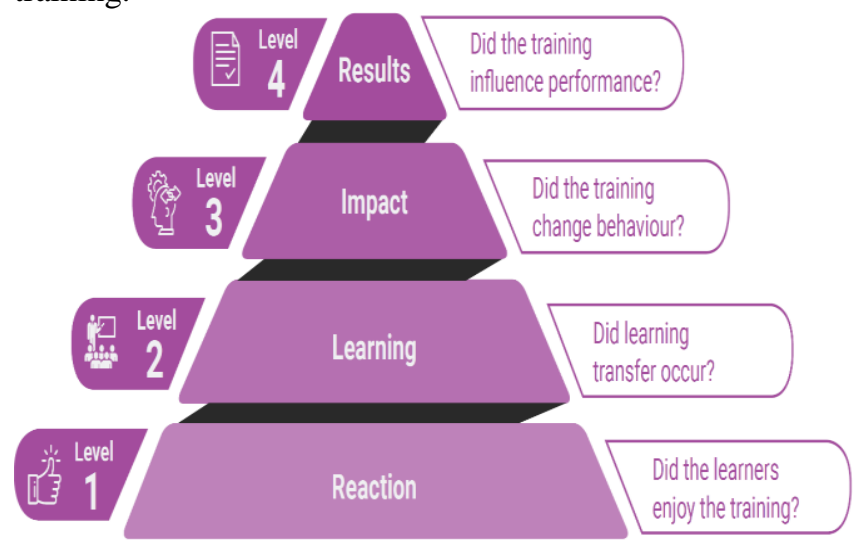

Figure 3. Details of Kirkpatrick's four levels of training evaluation (Adopted from Kirkpatrick \& Kirkpatrick, 2016)

The second model is Noe's model as shown in Figure 4. The model seems much ore complicate than Kirkpatrick's model. The three elements of environment, motivation, and reaction are the fundamental requirement to build Noe's model. However, there are more than one motivation and likewise for reaction.

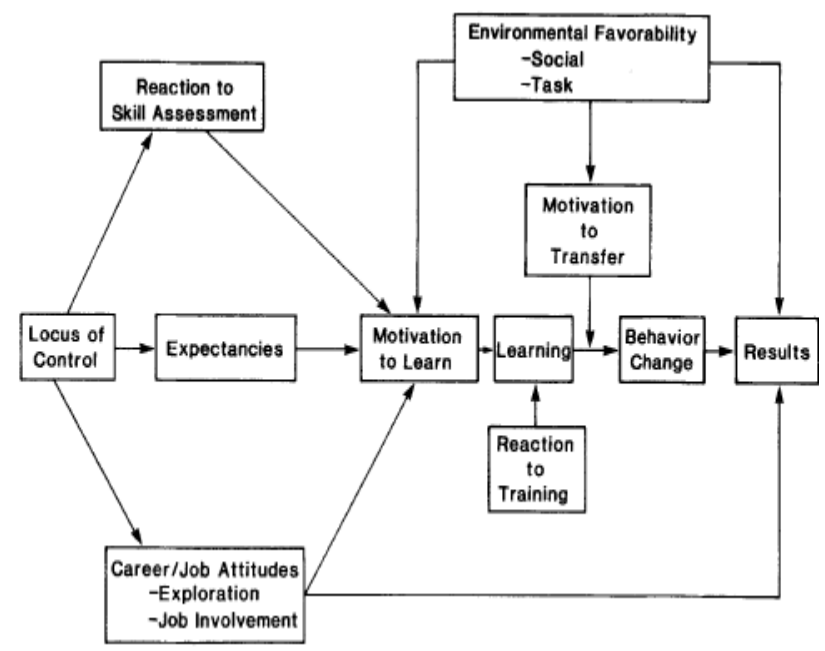

Figure 4. Noe's model for evaluating training effectiveness (Adopted from Noe \& Schmitt, 1986)

The third model is Swanson and Sleezer's model which was proposed in 1987. The approach of this model was guided by the fact that any gap between evaluation theory and practice could be minimized by implanting a system that ensures an effective methodology to evaluate a training program. The other requirement for building an effective model is the capability to implement such a model to any training program in the industry, education, and public service. Swanson \& Sleezer's model consists of three major elements: evaluation plan, measuring training effectiveness, and preparing a report. Throughout these three elements, a complete plan to assess the achievement of the training by assessing the tools, 
satisfaction, and performance. The resulting report should provide the management to make a suitable decision.

Transferring training has been recognized as one of the best tools to benefit individuals (trainees or trainers) by increasing clarity and getting motivation. Training is also considered as an opportunity for trainers and trainees to work together under a single mutual goal of improving the organization's outcome and enhance probability. The last beneficial is the society by improving the quality of the products, reducing cost, and providing a free environment of pollution towards a sustainable economy.

\section{FUTURE RESEARCH DIRECTIONS}

Training is a complex matter that is subjected to everlasting improvement in preparation, delivery, implementation, and contents. Training could affect a very wide sector in industry, education, government, sports, economy, military, and police. The goal of training is to improve the capability and country's wellbeing. In the last eight decades, uncountable research papers and studies have been conducted in all fields to improve training and $t$ achieve the goal of the effective training procedure. All these developments encounter, to a certain extent, some modifications, and/or improving to achieve that goal. The availability of so many studies has opened the way to evaluate the current status of training and move on towards better achievement by developing plans, models, and/or designs. However, the most important part of training -evaluating effectiveness- is still under consideration. The most important issue is to make training much effective and beneficial to all stakeholders and practitioners. Despite all these developments, certain parts of training issues are still looking for future improvement. The first issue is to study the influence of motivation on training effectiveness. Secondly, investigating the impact of attitude on the effectiveness of the organizations.

The third issue is developing better, unique, and much wider models that lead to a better understanding of the goal of training. Finally, the support of many organizations, especially in industry, to spend more and require certain annual hours of training to assure the best quality employees.

\section{CONCLUSION}

In this paper, a discussion about training, developments, and searching for models to evaluate training effectiveness. The paper has provided very influential and critical discussion to old papers as well as very recent papers. The factors that affect training, organizations, trainers, and trainees were exposed and thoroughly discussed. The most important part was how to evaluate the training and decided whether training is effective or not. The paper has concluded that training could be more effective when organizations focus on the content of the training and how to align this with the strategical goal of the organization. The study has declared that there were factors that should be considered immediately and given the highest priority: motivation, attitude, and emotional intelligence. These factors were determined throughout many studies as the dominant factors. This means, in particular, that managers have to motivate employees hoping to acquire new abilities and skills. Also, regarding ensuring better training effectiveness, managers have to allow employees to practice the acquired skills due to training at the workplace. The attitude of the trainees could be used as a criterion to make an initial assessment of how much the training effectiveness has been achieved. Despite the huge success of the tremendous studies about evaluating the training effectiveness, more studies are still needed in at least three dimensions: influence of motivation, the attitude of employees, and developing a better model.

\section{REFERENCES}

[1] Alaqeel, A., \& Aldoghmy, O. (2018). A literature review on effectiveness of computerized training programs on working memory capacity and reading ability of students with disabilities. European Journal of Special Education Research 3(3), 91-128.

[2] Aluko, F. R., \& Shonubi, O. K. (2014). Going beyond Kirkpatrick's Training Evaluation Model: The role of workplace factors in distance learning transfer. Africa Education Review, 11(4), 638-657.

[3] Armstrong, M., \& Taylor, S. (2020). Armstrong's handbook of human resource management practice. Kogan Page Publishers.

[4] Baldwin, T., \& Magjuka, R. J. (2014). Organizational context and training effectiveness. In Improving training effectiveness in work organizations (pp. 111-140). Psychology Press.

[5] Banfield, P., Kay, R., \& Royles, D. (2018). Introduction to human resource management. Oxford University Press.

[6] Beigi, M., \& Shirmohammadi, M. (2011). Effects of an emotional intelligence training program on service quality of bank branches. Managing Service Quality: An International Journal, Vol. 21 No. 5, pp. 552-567.

[7] Berman, E. M., Bowman, J. S., West, J. P., \& Van Wart, M. R. (2019). Human resource management in public service: Paradoxes, processes, and problems. CQ Press.

[8] Birdi, K. S. (2005). No idea? Evaluating the effectiveness of creativity training. Journal of European industrial training, Vol. 29 No. 2, pp. 102-111.

[9] Bisharat, H., Obeidat, B. Y., Alrowwad, A., Tarhini, A., \& Mukattash, I. (2017). The effect of human resource management practices on organizational commitment in chain pharmacies in Jordan. International Journal of Business and Management, 12(1), 50-67.

[10] Black, J. S., \& Mendenhall, M. (1990). Cross-cultural training effectiveness: A review and a theoretical framework for future research. Academy of management review, 15(1), 113-136.

[11] Bowman, S. R., Palomaki, J., Soares, L. B., \& Pitler, E. (2020). Collecting Entailment Data for Pretraining: New Protocols and Negative Results. arXiv preprint arXiv:2004.11997.

[12] Buchanan, D. A., \& Huczynski, A. A. (2019). Organizational behaviour. Pearson UK.

[13] Bumpass, S., \& Wade, D. (1990). Measuring participant performance: An alternative. Australasian Journal of Educational Technology, 6(2), 101-107.

[14] Burke, L. A., \& Baldwin, T. T. (1999). Workforce training transfer: A study of the effect of relapse prevention training and transfer climate. Human Resource Management: Published in Cooperation with the School of Business Administration, The University of Michigan and in alliance with the Society of Human Resources Management, 38(3), 227-241.

[15] Cameron, E., \& Green, M. (2019). Making sense of change management: A complete guide to the models, tools and techniques of organizational change. Kogan Page Publishers.

[16] Chen, G., Gully, S. M., \& Eden, D. (2004). General self-efficacy and self-esteem: Toward theoretical and empirical distinction between correlated self-evaluations. Journal of Organizational Behavior: The International Journal of Industrial, Occupational and Organizational Psychology and Behavior, 25(3), 375-395.

[17] Collins, J. W., Levy, J., Stefanidis, D., Gallagher, A., Coleman, M., Cecil, T., ... \& Pratschke, J. (2019). Utilising the Delphi process to develop a proficiency-based progression train-the-trainer course for robotic surgery training. European Urology, 75(5), 775-785.

[18] Colquitt, J. A., LePine, J. A., \& Noe, R. A. (2000). Toward an integrative theory of training motivation: a meta-analytic path analysis of 20 years of research. Journal of applied psychology, 85(5), 678-707.

[19] Dahiya, S., \& Jha, A. (2011). Review of training evaluation. International Journal of Computer Science and Communication, 2(1), $11-16$. 
[20] Driskell, T., Salas, E., \& Driskell, J. E. (2018). Teams in extreme environments: Alterations in team development and teamwork. Human Resource Management Review, 28(4), 434-449.

[21] Fadelelmoula, A. A. (2018). The effects of the critical success factors for ERP implementation on the comprehensive achievement of the crucial roles of information systems in the higher education sector. Interdisciplinary Journal of Information, Knowledge, and Management, 13(9), 21-44.

[22] Flippo, E. B. (1976). Principles of personnel management. McGraw-Hill.

[23] Glerum, D. R., Joseph, D. L., McKenny, A. F., \& Fritzsche, B. A. (2020). The trainer matters: Cross-classified models of trainee reactions. The Journal of applied psychology, 10.1037/apl0000503. Advance online publication. https://doi.org/10.1037/apl0000503

[24] Hammond, H., \& Churchill, R. Q. (2018). The role of employee training and development in achieving organizational objectives: A study of Accra Technical University. Archives of Business Research, 6(2), 67-74.

[25] Haslinda, A., \& Mahyuddin, M. Y. (2009). The effectiveness of training in the public service. American journal of scientific research, $6(1), 39-51$.

[26] Haywood, K. M. (1992). Effective training: Toward a strategic approach. Cornell Hotel and Restaurant Administration Quarterly, 33(6), 43-52.

[27] Hernawati, D., Amin, M., Irawati, M., Indriwati, S., \& Aziz, M. (2018). Integration of project activity to enhance the scientific process skill and self-efficacy in zoology of vertebrate teaching and learning. Eurasia Journal of Mathematics, Science and Technology Education, 14(6), $2475-2485$

[28] Hoel, T., \& Mason, J. (2018). Standards for smart education-towards a development framework. Smart Learning Environments, 5(1), 3-28.

[29] Homklin, T. (2014). Training effectiveness of skill certification system: The case of automotive industry in Thailand. Unpublished doctoral dissertation. Hiroshima University, Hiroshima, Japan.

[30] Jayawarna, D., Macpherson, A., \& Wilson, A. (2007). Training commitment and performance in manufacturing SMEs. Journal of small business and enterprise development, Vol 14(2), 321-338.

[31] Johnston, J. H., Burke, C. S., Milham, L. A., Ross, W. M., \& Salas, E. (2018). Challenges and propositions for developing effective team training with adaptive tutors. In Building Intelligent Tutoring Systems for Teams. Emerald Publishing Limited.

[32] Kirkpatrick, D. L. (1977). Evaluating training programs: Evidence vs. proof. Training Dev J., 31, 9-12.

[33] Kirkpatrick, D., \& Kirkpatrick, J. (2006). Evaluating training programs: The four levels. Berrett-Koehler Publishers.

[34] Kirkpatrick, J. D., \& Kirkpatrick, W. K. (2016). Kirkpatrick's four levels of training evaluation. Association for Talent Development.

[35] Landers, R. N., \& Armstrong, M. B. (2017). Enhancing instructional outcomes with gamification: An empirical test of the Technology-Enhanced Training Effectiveness Model. Computers in human behavior, 71, 499-507.

[36] Lee, H. J. (2018). How emotional intelligence relates to job satisfaction and burnout in public service jobs. International Review of Administrative Sciences, 84(4), 729-745.

[37] Lee, J. H., Jeong, H., \& Hong, S. C. (2018). Human capital and development: Lessons and insights from Korea's transformation. Edward Elgar Publishing.

[38] Mat, K., Omar, M. Z., Osman, S. A., Kofli, N. T., Rahman, M. N. A., Jamil, M., \& Jamaluddin, N. (2011). The effectiveness of industrial training on UKM engineering students. Procedia-Social and Behavioral Sciences, 18, 656-665.

[39] McCandlish, S., Kaplan, J., Amodei, D., \& Team, O. D. (2018). An empirical model of large-batch training. arXiv preprint arXiv: 1812.06162

[40] McDavid, J. C., Huse, I., \& Hawthorn, L. R. (2018). Program evaluation and performance measurement: An introduction to practice. Sage Publications.

[41] Mone, E. M., London, M., \& Mone, E. M. (2018). Employee engagement through effective performance management: A practical guide for managers. Routledge.

[42] Mooi, L. M. (2010). Teacher education: innovative, effectiveness and global. Procedia-Social and Behavioral Sciences, 9, 1815-1820.

[43] Morrison, G. R., Ross, S. J., Morrison, J. R., \& Kalman, H. K. (2019) Designing effective instruction. John Wiley \& Sons.

[44] Nankervis, A., Baird, M., Coffey, J., \& Shields, J. (2019). Human resource management. Cengage AU.

[45] Noe, R. A. (1986). Trainees' attributes and attitudes: Neglected influences on training effectiveness. Academy of management review, 11(4), 736-749.
[46] Noe, R. A., \& Kodwani, A. D. (2018). Employee training and development, 7e. McGraw-Hill Education.

[47] Noe, R. A., \& Kodwani, A. D. (2018). Employee training and development, 7e. McGraw-Hill Education.

[48] Noe, R. A., \& Schmitt, N. (1986). The influence of trainee attitudes on training effectiveness: Test of a model. Personnel psychology, 39(3), 497-523

[49] Pendić, Z. R., Pendić, R. Z., Jakovljević, B. B., Vujotić, L. B., \& Gajić, L. T. (2019). Where is the place of corporate security/safety in the organizational structure of an organization: An approach? Tehnika 74(5), 741-750.

[50] Postolache, O., Lourenço, F., Pereira, J. D., \& Girão, P. (2017, May). Serious game for physical rehabilitation: Measuring the effectiveness of virtual and real training environments. In 2017 IEEE International Instrumentation and Measurement Technology Conference (I2MTC) (pp. 1-6). IEEE

[51] Prifti, L., Levkovskyi, B., Knigge, M., \& Krcmar, H. (2018). Developing an Evaluation Model for Information Systems Curricula. In Proceedings of the $13^{\text {th }}$ international Conference $n$ Multikonferenz Wirtschaftsinformatik.

[52] Punia, B. K., \& Kant, S. (2013). A review of factors affecting training effectiveness vis-à-vis managerial implications and future research directions. International Journal of Advanced Research in Management and Social Sciences, 2(1), 151-164.

[53] Punia, B. K., \& Kant, S. (2013). A review of factors affecting training effectiveness vis-à-vis managerial implications and future research directions. International Journal of Advanced Research in Management and Social Sciences, 2(1), 151-164

[54] Quesada, C., Pineda-Herrero, P., \& Espona, B. (2011). Evaluating the efficiency of leadership training programmes in Spain. Procedia-Social and Behavioral Sciences, 30, 2194-2198.

[55] Rama, M. J., \& Vaishnavi, R. (2012). Measuring training effectiveness: a study in a leading retailing industry in a metropolitan city. EXCEL International Journal of Multidisciplinary Management Studies, 2(4), 16-25.

[56] Renah, A., \& Setyadi, D. (2014). The Influence of Organizational Culture, Working Environment and Educational Training on Motivation and Performance of Government Employees at West Kutai Regency East Kalimanatan. European Journal of Business and Management, 6(30), 182-191.

[57] Roberts, Z., Rogers, A., Thomas, C. L., \& Spitzmueller, C. (2018). Effects of proactive personality and conscientiousness on training motivation. International Journal of Training and Development, 22(2), 126-143.

[58] Robotham, D. (1995). Self-directed learning. Journal of European Industrial Training, Vol. 19 No. 7, pp. 3-7.

[59] Sahinidis, A. G., \& Bouris, J. (2008). Employee perceived training effectiveness relationship to employee attitudes. Journal of European Industrial Training, Vol. 32 No. 1, pp. 63-76.

[60] Sahoo, M., \& Mishra, S. (2019). Effects of trainee characteristics, training attitudes and training need analysis on motivation to transfer training. Management Research Review, Vol. 42 No. 2, pp. 215-238.

[61] Saks, A. M., Haccoun, R. R., \& Belcourt, M. (2010). Managing performance through training and development. Cengage Learning.

[62] Sangwa, N. R., \& Sangwan, K. S. (2018). Development of an integrated performance measurement framework for lean organizations. Journal of Manufacturing Technology Management, Vol. 29 No. 1, pp. 41-84.

[63] Sangwan, K. S., Bhakar, V., \& Digalwar, A. K. (2018). Sustainability assessment in manufacturing organizations. Benchmarking: An International Journal, Vol. 25 No. 3, pp. 994-1027.

[64] Santos, A., \& Stuart, M. (2003). Employee perceptions and their influence on training effectiveness. Human resource management journal, 13(1), 27-45

[65] Scaduto, A., Lindsay, D., \& Chiaburu, D. S. (2008). Leader influences on training effectiveness: motivation and outcome expectation processes. International Journal of Training and Development, 12(3), $158-170$.

[66] Shaban, O. S., Al-Zubi, Z., Ali, N., \& Alqotaish, A. (2017). The effect of low morale and motivation on employees' productivity \& competitiveness in Jordanian industrial companies. International Business Research, 10(7), 1-7.

[67] Shepherd, C. (1999). Assessing the ROI of Training. Available on www. fastrakconculting. com. uk. (Retrieved on March 23, 2012).

[68] Sitzmann, T., \& Weinhardt, J. M. (2018). Training engagement theory: A multilevel perspective on the effectiveness of work-related training Journal of Management, 44(2), 732-756.

[69] Sitzmann, T., \& Weinhardt, J. M. (2019). Approaching evaluation from a multilevel perspective: A comprehensive analysis of the indicators of 
training effectiveness. Human Resource Management Review, 29(2), 253-269.

[70] Sousa, M. J., \& Rocha, Á. (2019). Leadership styles and skills developed through game-based learning. Journal of Business Research, 94, 360-366.

[71] Sridhar, A. N., Briggs, T. P., Kelly, J. D., \& Nathan, S. (2017). Training in robotic surgery - an overview. Current urology reports, 18(8), 58-64.

[72] Stajkovic, A. D., Bandura, A., Locke, E. A., Lee, D., \& Sergent, K. (2018). Test of three conceptual models of influence of the big five personality traits and self-efficacy on academic performance: A meta-analytic path-analysis. Personality and individual differences, 120, 238-245.

[73] Steers, R. M., \& Porter, L. W. (1983). Motivation and work behavior. McGraw-Hill.

[74] Swanson, R. A., \& Sleezer, C. M. (1987). Training Effectiveness Evaluation. Journal of European Industrial Training, 11(4), 7-16.

[75] Swanson, R. A., \& Sleezer, C. M. (1987). Training Effectiveness Evaluation. Training Development and Research Center Project Number Sixteen.

[76] Swanson, R. A., \& Sleezer, C. M. (1987). Training Effectiveness Evaluation. Journal of European Industrial Training, 11(4), 7-16.

[77] Tabassi, A. A., Ramli, M., \& Bakar, A. H. A. (2012). Effects of training and motivation practices on teamwork improvement and task efficiency: The case of construction firms. International journal of project management, 30(2), 213-224.

[78] Tai, W. T. (2006). Effects of training framing, general self-efficacy and training motivation on trainees' training effectiveness. Personnel review, Vol. 35 No. 1, pp. 51-65.

[79] Tracey, J. B., Tannenbaum, S. I., \& Kavanagh, M. J. (1995). Applying trained skills on the job: The importance of the work environment. Journal of applied psychology, 80(2), 239-252.

[80] Van Loon, N., Kjeldsen, A. M., Andersen, L. B., Vandenabeele, W., \& Leisink, P. (2018). Only when the societal impact potential is high? A panel study of the relationship between public service motivation and perceived performance. Review of public personnel administration, 38(2), 139-166.

[81] Wenger, M., Sauli, F., Gross, V., \& Berger, J. L. (2019). Apprentices' Perceptions of Teachers' and In-Company Trainers' Skills at the Core of Training Quality. Contemporary Apprenticeship Reforms and Reconfigurations, 35, 88 .

[82] Zatsiorsky, V. M., Kraemer, W. J., \& Fry, A. C. (2020). Science and practice of strength training. Human Kinetics.

[83] Zatsiorsky, V. M., Kraemer, W. J., \& Fry, A. C. (2020). Science and practice of strength training. Human Kinetics. 